\title{
Teratogenicity of Zinc Deficiency in the Rat: Study of the Fetal Skeleton
}

\author{
R.M.C. Da Cunha Ferreira, I. Monreal Marquiegui, and I. Villa Elizaga \\ Departments of Pediatrics (R.M.C.C.F., I.V.E.) and Biochemistry (I.M.M.) \\ University Clinic of Navarra, University of Navarra, Pamplona, Spain
}

Address reprint requests to Dr. Roque M.C. da Cunha Ferreira, Department of Pediatrics, Hospital de Santa Maria, Universidade de Lisboa, Au. Egas. Moni, 1699 LISBOA Codex, Portugal.

\begin{abstract}
Zinc deficiency (ZD) is teratogenic in rats, and fetal skeletal defects are prominent. This study identifies fetal skeletal malformations that affect calcified and non-calcified bone tissue as a result of gestational zinc deficiency in rats, and it assesses the effect of maternal ZD in fetal bone calcification. Pregnant Sprague-Dawley rats (180-250 g) were fed 1) a control diet (76.4 $\mu \mathrm{g} \mathrm{Zn/g} \mathrm{diet)} \mathrm{ad} \mathrm{libitum} \mathrm{(group} \mathrm{C),} \mathrm{2)} \mathrm{a} \mathrm{zinc-deficient} \mathrm{diet} \mathrm{(0}$ $\mu \mathrm{g} / \mathrm{g}$ ) ad libitum (group ZD), or 3) the control diet pair-fed to the ZD rats (group PF). On day 21 of gestation, laparotomies were performed. Fetuses were weighed, examined for external malformations, and stained in toto with a double-staining technique for the study of skeletal malformations. Maternal and fetal tissues were used for $\mathrm{Zn}, \mathrm{Mg}, \mathrm{Ca}$, and $\mathrm{P}$ determinations. Gross external malformations were present in $97 \%$ of the ZD fetuses. No external malformations were found in fetuses from groups $\mathrm{C}$ and PF. Ninety-one percent of cleared ZD fetuses had multiple skeletal malformations, whereas only $3 \%$ of the fetuses of group PF had skeletal defects; no skeletal malformations were found in fetuses from group $\mathrm{C}$. Some of the skeletal malformations described in the ZD fetuses, mainly affecting non-calcified bone, were not mentioned in previous reports, thus stressing the importance of using double-staining techniques. Examination of stained fetuses and counting of ossification centers revealed important calcification defects in $\mathrm{ZD}$ fetuses. These effects were confirmed by lower $\mathrm{Ca}$ and $\mathrm{P}$ concentrations in fetal bone with alteration of the $\mathrm{Ca}: \mathrm{P}$ ratio.
\end{abstract}

\section{INTRODUCTION}

Severe maternal zinc deficiency (ZD) is known to be teratogenic in rats. Fetal malformations due to maternal zinc deficiency affect almost every tissue and skeletal mal-formations have been reported (Hurley and Swenerton, '66; Hurley and Mutch, '73; Vojnik and Hurley, '78; Hickory et al., '79; Masters et al., '83; Rogers et al., '85). 
Previous studies using stained fetuses (Hurley and Swenerton, '66; Hickory et al., '79; Rogers et al., '85) searched only for abnormalities of calcified bone and thus were not able to provide information about cartilage defects. In the present study we used a double-staining technique for bone and cartilage to identify skeletal malformations in both calcified and non-calcified bone tissue from fetuses of ZD dams. This has enabled us to detect previously unrecognized malformations that involved mainly non-calcified bone. Counting of ossification centers of sternum, hands and feet, and fetal bone determinations of $\mathrm{Ca}$ and $\mathrm{P}$ concentrations were performed to assess skeletal calcification, which was found to be impaired in $\mathrm{ZD}$ fetuses. Maternal bone concentrations of $\mathrm{Ca}$ and $\mathrm{P}$ also were determined. The effect of maternal zinc deficiency on tissue concentration of $\mathrm{Zn}$ in the dams and fetuses was examined to confirm the deficiency state.

\section{MATERIALS AND METHODS}

Virgin female Sprague-Dawley rats (180 - $250 \mathrm{~g})$ were purchased from a commercial source (Panlab, S.A., Barcelona, Spain). They were individually housed in suspended stainless steel cages in a room controlled for temperature $\left(20-25^{\circ} \mathrm{C}\right)$ and light $(13 / 11 \mathrm{hr}$ light/dark cycle). All animals were acclimated for a minimum of 7 days and were fed a complete purified diet (Table 1). Females were mated overnight with stock-fed males of the same strain. Mating was confirmed by the presence of vaginal plugs and/or spermpositive smears. On day 0 of gestation rats were divided into three groups and fed 1) the control diet (Table 1) ad libitum (group $\mathrm{C}, \mathrm{n}=8$ ); 2) a severe zinc-deficient diet ad libitum (group $\mathrm{ZD}, \mathrm{n}=8$ ); and 3 ) the control diet in restricted amounts on a one-to-one basis to the. ZD animals (group PF, $\mathrm{n}=8$ ). The composition of the zinc-deficient diet was similar to that of the control diet, except that it did not contain $\mathrm{ZnCO}_{3}$. All rats received distilled deionized water ad libitum.

The diets were analyzed at the beginning and at regular intervals during the experiment. Zinc concentration (mean) of the control diet was $76.4 \mu \mathrm{g} / \mathrm{g}$; that of the deficient diet was below the sensitivity of the method used $(0.05 \mu \mathrm{g} / \mathrm{g})$ and is thus expressed as 0 $\mu \mathrm{g} / \mathrm{g}$. Both the control and the deficient diet were found to contain (mean): Fe 103.5 $\mu \mathrm{g} / \mathrm{g}, \mathrm{Cu} 7.1 \mu \mathrm{g} / \mathrm{g}, \mathrm{Ca} 9.2 \mathrm{mg} / \mathrm{g}$, and $\mathrm{Mg} 1.0 \mathrm{mg} / \mathrm{g}$. Extreme care was taken on the manufacture and manipulation of the diets to avoid contamination: all ingredients were provided in plastic or glass containers; diets were always prepared and mixed by Dr. Roque M.C. da Cunha Ferreira in previously EDTA-washed mixer and subsequently stored in double-plastic bags; diets were only manipulated by Dr. Cunha Ferreira and Dr. I. Monreal Marquiegui with disposable plastic gloves.

Daily food intake as well as weight of the dams on days $0,5,10,15$, and 21 were measured. On day 21 of gestation dams were anesthetized with ether and laparotomies were performed.

Blood was collected by cardiac puncture into disposable plastic syringes (Sardstead, Numbrecht, Federal Republic of Germany) with Zinc-free heparin (Sigma Chemical Co., St. Louis, MO). Blood was centrifuged for $10 \mathrm{~min}$ at 3,000 rpm, and the plasma was removed with plastic transfer pipettes (Sardstead) and stored in disposable polystyrene tubes until analyzed. 
The number of live fetuses and resorptions (detected by persistence of metrial nodes) was counted. The fetuses were removed, weighed, asid examined for external malformations. All fetuses, except two in each uterine horn (used for bone analysis and histology), were immediately sacrificed, eviscerated, stained in toto with alizarin red and alcian blue, and cleared according to the method of Kimmel and Trammel ('81). The fetuses were then examined blind for skeletal malformations and for assessment of skeletal calcification. The number of ossification centers in the sternum, hands (metacarpals and anterior proximal phalanges), and feet (metatarsals) were used as indicators of skeletal calcification (Aliverti et al., '79).

Maternal bone and fetal liver and bone were removed, washed in distilled deionized water, and stored in plastic film at $4{ }^{\circ} \mathrm{C}$ for subsequent analysis. The livers from all fetuses of each dam were pooled, and fetal bone determinations were done on tibiae extracted from one fetus in each litter.

Zinc, copper, calcium, and magnesium concentrations were determined by flame atomic absorption spectrophotometry (Perkin-Elmer, model 305-B, Perkin-Elmer Corp., Norwalk, CN). Concentrations of iron and phosphorus were determined by a colorimetric method (Merck, Darmstadt, Federal Republic of Germany) with a spectrophotometer "Zeiss-PM2" (Carl Zeiss, Oberkochen, Federal Republic of Germany). Solid samples were previously ashed in concentrated nitric acid (16 M) according to Clegg et al. ('81).

One-way analysis of variance, chi-square, and Duncan's multiple range test were used to evaluate statistical significance. Correlation coefficient was assessed by the Pearson product moment. A probability of less than 0.05 was considered significant. The litter was used as the statistical unit for calculation of fetal weight and ossification nuclei, and so these values represent means of litter means within each group.

\section{RESULTS}

\section{Maternal food intake and weight gain during pregnancy}

Maternal food intake and weight gain during gestation were significantly affected by dietary zinc deficiency (Table 2). Dams fed the zinc-deficient diet (group ZD) ate significantly less than those of group C. Food intake of ZD dams decreased significantly from day 5 onward, following a 4-day cyclic pattern, and it was minimal in the last 4 days of gestation (Fig. 1). Accordingly, at the end of gestation, ZD dams had gained significantly less weight than did C or PF dams. Significant differences between the weight of the dams of groups ZD and $\mathrm{C}$ were already present by day 10 (Table 3). By day 15 there were also significant differences between the weight of the dams of groups $\mathrm{ZD}$ and $\mathrm{PF}$.

\section{Reproductive parameters / external malformations}

Dietary zinc deficiency during gestation had severe effects on reproductive parameters as summarized in Table 4. Fetal weight was significantly less in ZD fetuses compared with $\mathrm{C}$ and PF fetuses. All litters from $\mathrm{ZD}$ dams had malformed fetuses, and gross 
external malformations were present in $97 \%$ of all ZD fetuses (Table 5). Defects of the tail and extremities occurred in $88 \%$ and $86 \%$ of all ZD fetuses, respectively, and were present in all litters. There was also a high frequency of malformations of the head $(47 \%)$ and trunk (39\%) in fetuses of group ZD (Fig. 2). On external observation, no malformations were found in fetuses from groups $\mathrm{C}$ and $\mathrm{PF}$.

\section{Skeletal malformations}

The study of cleared specimens revealed that $91 \%$ of the 44 fetuses examined in group ZD had skeletal malformations, whereas only $3 \%$ of 74 fetuses examined from group $\mathrm{PF}$ and none of 63 fetuses examined from group $\mathrm{C}$ were affected. Skeletal malformations found in fetuses of group PF were fused vertebrae (one fetus) and double hemi-vertebrae (one fetus). Bilobulated vertebrae and different configurations of the xiphoid process were found in all groups. In the ZD group, malformations of the tail (100\% of specimens examined-35/35) (Fig. 3a), ribs (84\%-36/43) (Fig. 3b-e), and extremities (68\%-30/44) (Figs. 4 and 5) were found in all eight litters. There were malformations of the spine (74\%-32/43) (Fig. 3bc) in seven litters; malformations of the sternum $(50 \%-15 / 30)$ were present in five litters and micrognathia $(25 \%-11 / 44)$ in three.

Fetal skeletal malformations found in ZD fetuses are presented in Table 6. In relation to malformations of the appendicular skeleton, forelimbs were malformed in $66 \%$ of the specimens examined (29/44) and the hindlimbs in 39\% (16/41), affecting eight and seven litters, respectively. Malformations of proximal segments were generally bilateral, while malformations of the hands and feet (except oligodactylies) were mostly unilateral. In a total of nine fetuses from two litters the forearm had a single curved bone with radial convexity (Fig. 4ab); its proximal end was similar to the olecranon, while its distal end was similar to the distal epiphysis of the radius. In eight of these nine fetuses the bone of the forearm continued the humerus by a synarthrosis. One fetus from a different litter exhibited shortening of the forearm with the ulna curved over the radius. In each of these ten cases there was a lateral deviation of the hand. Whenever present, clinodactyly was also laterally orientated. Oligodactyly was mostly bilateral and, with two exceptions, there were always four digits present; missing digits were from the central group and occasionally it was the fifth digit. Oligodactyly resulted from total transverse fusion of phalanges in three cases. With respect to the hindlimbs, $80 \%$ of tibial defects were a curved bone over an hypoplastic fibula (Fig. 5a-d). Oligodactylies were always due to lack of digits of the central group, except in one case when total transversal fusion of phalanges was present.

\section{Calcification defects}

Malformations in the fetal skeleton of ZD fetuses were accompanied by major defects of skeletal calcification. In many cases the long bones of ZD fetuses showed smaller areas of calcification than the controls or no calcification at all. There were no signs of calcification of the fibula in $27 \%$ of the specimens examined (11/41), affecting fetuses from five litters (Fig. 5a-d). The number of ossification nuclei in the sternum, hands, and feet was significantly lower in the fetuses of the ZD group (Table 7). 


\section{Tissue trace element concentrations}

Dietary zinc deficiency during gestation had a significant effect on zinc concentrations of maternal tissues (Table 8). Plasma and bone zinc concentrations were lower in the ZD dams than in either PF or $\mathrm{C}$ dams. Plasma $\mathrm{Zn}$ concentrations in $\mathrm{PF}$ dams was also lower than in $\mathrm{C}$ dams. There were no significant differences in maternal bone zinc among groups $\mathrm{PF}$ and $\mathrm{C}$. Zinc concentrations in fetal liver were not influenced by maternal zinc deficiency, while those of fetal bone were significantly lower in the ZD group. There was no significant effect of maternal dietary zinc deficiency on calcium and phosphorus concentrations in maternal plasma and bone. Concentrations of $\mathrm{Ca}$ and $\mathrm{P}$ in fetal bone were significantly lower in group $\mathrm{ZD}$ compared with groups $\mathrm{PF}$ and $\mathrm{C}$. Ca:P ratio was also significantly lower in group ZD. Considering all three groups, there was a correlation $(\mathrm{P}<.001)$ between fetal bone zinc concentrations and fetal bone $\mathrm{Ca}(\mathrm{r}=0.80), \mathrm{P}(\mathrm{r}=0.75)$, and $\mathrm{Ca}: \mathrm{P}$ ratio $(\mathrm{r}=0.77)$. Maternal dietary zinc deficiency had no effect on magnesium concentrations in maternal and fetal tissues.

\section{DISCUSSION}

\section{Maternal food intake and weight gain}

The decrease in food intake and the cyclic pattern of intake found in ZD dams are common findings in animals fed zinc-deficient diets and have been reported in nonpregnant and pregnant rats (Chesters and Quarterman, '70; Williams and Mills, '70; Chesters and Will, '73; Masters et al., '83; Rogers et al., '85). There is still controversy about the mechanisms involved in causing both phenomena (Chesters and Quarter-man, '70; Chesters and Will, '73; Wallwork et al., '81; Masters et al., '83; Rogers et al., '85). Apparently the cyclic pattern of food intake is due to alternate periods of protein catabolism and anabolism secondary to decreased food intake and tissue zinc liberation, respectively (Chesters and Will, '73; Masters et al., '83). From day 17 of gestation until day 21 the ZD dams ate minimal amounts of the diet, and this has been correlated with the higher requirements of the maternal-fetal unit at this stage (Masters et al., '83; Rogers et al., '85): the rapid fetal accumulation of zinc in the last days of gestation would not allow the maternal reutilization of the zinc liberated from tissue catabolism, thus diminishing further food intake (Feaster et al., '55; Hurley and Swenerton, '71; Williams et al., '77; Masters et al., '83).

Total weight gain and net weight gain were significantly less in ZD dams, due to both lower food intake and lower food efficiency. These findings agree with those of previous studies (Hurley and Swenerton, '66; Vojnik and Hurley, '78; Masters et al., '83; Reinstein et al., '84; Rogers et al., '85). There is lack of agreement as to whether differences in total weight gain merely reflect the differences in the weight of the uterus plus the fetuses, placentae, and adhering membranes (Rogers et al., '85) or correspond to weight changes in the dams. In the present study we found a significantly lower net weight of the dams. Also, the fact that at day 15 of gestation, that is, prior to the period of rapid fetal growth, there were already significant differences between the weight of the dams of groups ZD and PF indicates that zinc deficiency affects the growth of the pregnant rat. 


\section{Prenatal development}

In the present study maternal zinc deficiency severely affected embryonic and fetal development. A higher percentage of resorptions (Vojnik and Hurley, '78; Masters et al., '83; Rogers et al., '85), a lower fetal weight (Hurley and Swenerton, '66; Vojnik and Hurley, '78; Masters et al., '83; Reinstein et al., '84; Rogers et al., '85), and a high incidence of malformations (Hurley and Swenerton, '66; Hurley and Mutch, '73; Reinstein et al., '84; Rogers et al., '85) as a consequence of maternal zinc deficiency have been extensively reported in the literature. There is a wide variation in the percentage of malformed fetuses reported (45-98\%); this is mainly due to different methods and criteria of evaluation. Some authors consider external malformations exclusively (Hurley and Mutch, '73; Reinstein et al., '84), while others include visceral and/or skeletal malformations (Hurley and Swenerton, '66). Hurley and Cosens ('74) described a relationship between the concentration of zinc in the diet of pregnant rats and the frequency of fetal malformations. They reported that feeding diets containing 0.4-1.25 $\mu \mathrm{g} \mathrm{Zn/g}$ diet to Sprague-Dawley rats caused almost all fetuses to be malformed. When the dietary zinc content was increased to $2.5 \mu \mathrm{g} / \mathrm{g}$, the frequency of malformed fetuses decreased to $67 \%$. The percentage of malformed fetuses $(99 \%)$ found in our study (considering external and skeletal malformations) is in accordance with the data of Hurley and Cosens ('74) and is also similar to the $98 \%$ described earlier by Hurley and Swenerton ('66).

\section{External malformations}

External malformations found in ZD fetuses corresponded with those reported by other authors (Hurley and Swenerton, '66; Hurley and Mutch, '73; Hickory et al., '79; Masters et al., '83; Reinstein et al., '84; Rogers et al., '85). We did not find some malformations mentioned in other studies, such as anencephaly (Hurley and Mutch, '73), hydroanencephaly (Hurley and Swenerton, '66), and cleft palate (Hurley and Swenerton, '66; Hurley and Mutch, '73; Masters et al., '83; Reinstein et al., '84; Rogers et al., '85), as the study of these malformations requires sectioning for internal examination (Wilson, '65). Abnormal curvatures of the spine have not been considered because of the pliable nature of the fetuses. The incidence of external malformations varies in the different studies; comparing our findings with those of other authors using a different protein source (Cox et al., '69), different dietary zinc concentration (Masters et al., '83; Reinstein et al., '84), or other animal strain (Rogers et al., '85), we assume that when contamination is ruled out, the main source of variation is dietary zinc concentration. Indeed, the concentration of zinc in the diets used by Masters et al. ('83) and Reinstein et al. ('84) was just slightly higher $(0.7 \mu \mathrm{g} / \mathrm{g}$ and $1.2 \mu \mathrm{g} / \mathrm{g})$ than that in our diet, and the incidence of external malformations was much lower. Nevertheless, the decreased incidence of malformations when small amounts of zinc are present was documented by Fosmire et al. ('77); this group found that the addition of $1 \mu \mathrm{g} \mathrm{Zn/g}$ to a zinc-deficient diet prevents teratogenesis. Also, different methods of observation may account, to some extent, for the differences found.

The mechanisms involved in the genesis of malformations due to maternal zinc deficiency are as yet unknown. They can probably be explained by the fundamental role of zinc in the synthesis of proteins and nucleic acids (Hurley, '81). 


\section{Skeletal malformations}

The main interest in using in toto staining techniques is that the observation of cleared fetuses reveals skeletal malformations not discernible by external observation or sectioning. The high number of skeletal malformations found in ZD fetuses and their type and distribution agrees with the findings of other authors (Hurley and Swenerton, '66; Hickory et al., '79; Rogers et al., '85). Many of these malformations correspond with the external malformations. As for the other groups, a binucleated vertebral body, as that found in a fetus from group PF, can be considered a variant of normal, as it affected only one vertebra (Kimmel and Wilson, '73); bilobulated vertebral centrae and different configurations of the xiphoid process that were found in fetuses from all groups are also variants of normal (Kimmel and Wilson, '73). It is difficult to compare different studies in relation to the type and frequency of skeletal malformations. Although previous reports (Hurley and Swenerton, '66; Hickory et al., '79; Rogers et al., '85) described the more frequent skeletal defects, the type of malformations described are scarce, and observations lack many details. Several skeletal malformations described in the present study such as vertebral fusion, absence of the sternum, dysplasia of long bones, synarthrosis, synchondrosis, fusion of metacarpals and metatarsals, clinodactyly, and duplications have not been acknowledged.

Methods used by other authors (Hurley and Swenerton, '66; Hickory et al., '79; Rogers et al., '85) could only reveal calcified bone, thus giving limited information on the fetal skeleton, especially if the stage of calcification of the term fetus is considered. We believe that some bones reported to be missing in earlier works, namely, the mandible (Hurley and Swenerton, '66), vertebrae (Hurley and Swenerton, '66), and tibia (Hickory et al., '79; Rogers et al., '85) were possibly present and would have been identified if cartilage had been stained.

Double-staining techniques reveal both calcified and non-calcified bone tissue and thus enable a much more detailed and precise study of the fetal skeleton. A correct and comprehensive description and classification of skeletal fetal malformations can only be done when such methods are used. The study of double-stained specimens provides additional information on the teratogenic effects of maternal zinc deficiency. We found defects resulting from insults at different stages of embryonic and fetal development, thus confirming the rapid effect of nutritional zinc deficiency and a constant need of a maternal supply of this metal throughout gestation. Also, the wide distribution of skeletal malformations reflects a generalized defect, suggesting a deviation in essential metabolic pathways.

Although skeletal malformations due to maternal zinc deficiency could well be attributed to defects in the synthesis of proteins and nucleic acids, it is likely that more specific mechanisms are also involved. Zinc is known to play a role in bone metabolism at various levels. Zinc influences regulatory mechanisms of bone growth, namely, calcium regulatory hormones such as vitamin $\mathrm{D}_{3}$ (Yamaguchi and Sakashita, '86) and growth factors such as somatomedin C (Cossack, '84; Oner et al., '84). On a local level, it has been demonstrated that zinc is involved in the metabolism of the bone and cartilage matrix, in cellular proliferation and function, and in the process of calcification. It is needed for collagen synthesis (Bergman et al., '70; Fernandez-Madrid et al., '71, '73; Philip and Kurup, '78; Starcher et al., '80; Suwarnasarn et al., '82) and metabolism (Starcher et al., '80; Suwarnasarn et al., '82) and for the synthesis of 
glycosaminoglycans (Lema and Sandstead, '70; Philip and Kurup, '78; Suwarnasarn et al., '82). Morphological and functional derangements of chondrocytes in endochondral growth sites (Diamond and Hurley, '70; Bergman et al., '70, '72; Suwarnasarn et al., '82) and of osteoblasts (Follis et,al., '41; Bergman et al., '70) have been described in ZD rats. A role for zinc in the division and maturation of chondrocytes and in the differentiation and functional ability of osteoblasts and osteoblasts has been confirmed in skeletal tissue organ culture (Rest, '76). The role of zinc in the process of calcification is discussed below.

\section{Skeletal calcification}

Fetuses from ZD dams showed major defects of skeletal calcification and retarded skeletal development, as evidenced by significantly fewer calcification nuclei in the sternum, hands, and feet. These ossification defects found in the ZD fetal skeleton concur with the biochemical data. Ossification defects in the skull, vertebrae, ribs, and long bones, and missing ossification centers in the sternum, hands, and feet of ZD fetuses have been mentioned in previous works (Hurley and Swenerton, '66; Hickory et al., '79; Rogers et al., '85), but evaluation was mainly based on subjective interpretation of fetal ossification. Counting of ossification nuclei in 21-day fetuses provides objective data in determining the stage of skeletal ossification, which, in turn, is a reliable index for evaluating fetal development (Ali-verti et al., '79). Defective bone mineralization and a delay in skeletal maturation in association with gestational zinc deficiency have been shown in other animals (Hurley, '81), including primates (Leek et al., '84). Similar effects have also been described as a result of post-natal zinc deficiency in animals (Calhoun et al., '74; Leek et al., '88), and in man (Halsted et al., '72); these effects are reversed by zinc supplementation (Calhoun et al., '74; Ronaghy et al., '74). Zinc is necessary in the process of calcification; possible mechanisms involved are mentioned below.

\section{Tissue zinc, calcium and phosphorus}

Maternal zinc deficiency had a significant effect on zinc concentrations in maternal plasma and bone and in fetal bone. Plasma zinc is considered to be a good indicator of zinc status in controlled experimental conditions (Walker and Kelleher, '78); the significantly lower values in group ZD confirmed the maternal zinc deficiency in this group. Bone (tibia) zinc concentration was significantly decreased in ZD dams, confirming the data of previous studies (Hurley and Swenerton, '71). No differences were found in bone concentrations of calcium and phosphorus, supporting the findings of Murray and Messner ('81) that the lower bone zinc concentration found in ZD animals reflect a decreased incorporation of the metal in bone tissue, rather than its liberation from this tissue. In the fetuses from ZD dams bone zinc concentrations were significantly lower, but liver zinc concentration was similar to that found groups PF and C.

Other authors noted a significant decrease in zinc concentration in fetal liver (Hurley and Swenerton, '71; Halas et al., '82; Hurley et al., '83; Reinstein et al., '84; Rogers et al., '85) and bone (Halas et al., '82). It is possible that the normal fetal liver zinc found in this study represents the initial phase of the metabolic cycle of zinc liberated from 
maternal tissues, mainly in the last days of gestation (Masters et al., '83) which is rapidly transferred to the fetus (Feaster et al., '55). We cannot agree 'with Halas et al. ('82) who have considered fetal liver and bone zinc concentrations to reflect fetal zinc metabolic status. Our results indicate that fetal liver zinc is not useful as an indicator of zinc status in the term fetus. We did not find any effect of gestational zinc deficiency in the magnesium status of the dams and the fetuses.

Maternal zinc deficiency did not affect calcium and phosphorus concentrations in maternal plasma. Previous work in pregnant rats (Hurley and Tao, '72) also showed no effect of maternal zinc deficiency in serum calcium. Tibiae from ZD fetuses had significantly lower calcium and phosphorus concentrations when compared with those of other groups. Ca:P ratio also was affected, indicating an impairment of bone calcification and confirming the observations in stained fetuses. Kinetic studies with ${ }^{45} \mathrm{Ca}$ in ZD young rats revealed a specific alteration of calcium metabolism, namely, a decrease in calcium incorporation and bone anabolism (Hurley et al., '69). Other authors (Brown et al., '78; Murray and Messner, '81) also demonstrated less accumulation of calcium and phosphorus in bone of zinc-deficient young rats, with no alteration of $\mathrm{Ca}: \mathrm{P}$ ratio.

We could not find any previous data on calcium and phosphorus concentrations in ZD fetal bone. Biochemical determinations of $\mathrm{Ca}$ and $\mathrm{P}$ in fetal bone confirm the observations of severe defects in calcification detected in stained specimens. According to Brown et al. ('78), $\mathrm{Zn}: \mathrm{Ca}$ and $\mathrm{Zn}: \mathrm{P}$ ratios are not important in the mechanisms of calcification. Apparently, the role of zinc in the process of calcification is nonstructural, acting as a co-factor or catalyst in that process (Brown et al., '78). This is probably related to the activation of alkaline phosphatase, a zinc-metalloenzyme that plays a fundamental role in bone calcification (Bourne, '72; Matsuzawa and Anderson, 171; Salomon, '74). Supporting this hypothesis is the fact that an important part of skeletal zinc is found in areas of active calcification (Haumont, '61; Haumont and Vincent, '61; Haumont and MacLean, '66; Bergman, '70; Vincent, '63) in association with alkaline phosphatase (Aitken, '76). It has been shown in rats that zinc deficiency reduces the activity of bone alkaline phosphatase (Prasad et al., '67; Prasad and Oberleas, '71; Huber and Gershoff, '73; Roth and Kirchgessner, '74; Adeniyi and Heaton, '80), an effect that is rapidly reversed with zinc repletion (Prasad et al., '67; Roth and Kirchgessner, '74). On the other hand, oral administration of zinc sulfate to weanling rats produces an increase in bone alkaline phosphatase (Yamaguchi and Yamaguchi, '86). Interestingly enough, when all groups were considered, Zn concentrations of fetal bone correlated significantly with $\mathrm{Ca}$ and $\mathrm{P}$ concentrations. This suggests a close dependency of $\mathrm{Ca}$ and $\mathrm{P}$ accumulation in bone on the amount of $\mathrm{Zn}$ present, thus stressing the importance of this trace metal in the mechanisms of calcification.

In summary, the present study has provided further evidence of the high incidence of skeletal malformations in fetuses from severe zinc-deficient dams, with information on defects of non-calcified bone. It has also shown a significant impairment of calcification in $\mathrm{ZD}$ fetal skeleton, confirming a defective fetal development. 


\section{ACKNOWLEDGMENTS}

This work was supported by a grant from Fundación Echebano (Pamplona, Spain). EDDA-Uniasa (Granada, Spain) kindly provided the vitamin mix and the salt mix for the diets. The authors thank Dr. Michael J.G. Farthing, M.D., M.R.C.P, for reviewing the manuscript, and Dr. João M.B. Cabral and Mr. Duarte Trigueiros for their statistical advice. Dr. Roque da Cunha Ferreira was supported in part by a research grant from Fundação Calouste Gulbenkian (Lisbon, Portugal).

\section{LITERATURE CITED}

1. Adeniyi, F.A., and F.W. Heaton (1980) The effect of zinc deficiency on alkaline phosphatase (EC 3.1.3.1) and its isoenzymes. Br. J. Nutr., 43:561-569.

2. Aitken, J.M. (1976) Factors affecting the distribution of zinc in the human. Calcif. Tissue Res., 20:23-30.

3. Aliverti, V., L. Bonanomi, E. Giavini, V.G. Leone, and L. Marione (1979) The extent of fetal ossification as an index of delayed development in teratogenic studies on the rat. Teratology, 20:237-242.

4. Bergman, B. (1970) The distribution of ${ }^{65} \mathrm{Zn}$ in the endochondral growth sites of the mandibular condyle and proximal end of the tibia in young rats: An autoradiographic and gamma scintilation study. Odontol. Revy., 21:1-4.

5. Bergman, B., U. Friberg, S. Lohmander, and T. Öberg (1970) Morphologic and autoradiographic observations on the effect of zinc deficiency on endochondral growth sites in the white rat. Odontol. Revy., 21 :379-399.

6. Bergman, B., U. Friberg, S. Lohmander, and T. Öberg (1972) The importance of zinc to cell proliferation in endochondral growth sites in the white rat. Scand. J. Dent. Res., 80:486-92.

7. Bourne, G.H. (1972) Phosphatase and calcification. In: The Biochemistry and Physiology of Bone. G.H. Bourne, ed. Academic Press, New York, Vol. 2, pp. 79120.

8. Brown, E.D., W. Chan, and J.C. Smith (1978) Bone mineralization during a developing zinc deficiency. Proc. Soc. Exp. Biol. Med., 157:211-214.

9. Calhoun, N.R., J.C. Smith, and K.L. Becker (1974) The role of zinc in bone metabolism. Clin. Orthop., 103:212-234.

10. Chesters, J.K., and J. Quarterman (1970) Effects of zinc deficiency on food intake and feeding patterns of rats. Br. J. Nutr., 24:1061-1069.

11. Chesters, J.K., and M. Will (1973) Some factors controlling food intake by zincdeficient rats. Br. J. Nutr., 30:555-566.

12. Clegg, M.S., C.L. Keen, B. Lönnerdal, and L.S. Hurley (1981) Influence of ashing techniques on the analysis of trace elements in animal tissue. I. Wet ashing. Biol. Trace Element Res., 3:107-115.

13. Cossack, Z.T. (1984) Somatomedin-C and zinc deficiency. Experientia, 40:498.

14. Cox, D.H., R.C. Chu, and S.A. Schlicker (1969) Zinc deficiency in the maternal rat during gestation and zinc, iron, copper and calcium content and enzyme activity in maternal and fetal tissues. J. Nutr., 98:449-458.

15. Diamond, I., and L.S. Hurley (1970) Histopathology of zinc-deficient fetal rats. J. Nutr., 100:325-329. 
16. Feaster, J.P., S.L. Hansard, J.T. McCall, and G.K. Davis (1955) Absorption, deposition and placental transfer of zinc-65 in the rat. Am. J. Physiol., 181:287-290.

17. Fernandez-Madrid, F., A.S. Prasad, and D. Oberleas (1971) Effect of zinc deficiency on collagen metabolism. J. Lab. Clin. Med., 78:853.

18. Fernandez-Madrid, F., A.S. Prasad, and D. Oberleas (1973) Effect of zinc deficiency on nucleic acids, collagen and noncollagenous protein of connective tissue. J. Lab. Clin. Med., 82:951-961.

19. Follis Jr, R.H., H.G. Day, and E.V. McCollum (1941) Histological studies of the tissues of rats fed a diet extremely low in zinc. J. Nutr., 22:223-237.

20. Fosmire, G.J., S. Greeley, and H.H. Sandstead (1977) Maternal and fetal response to various sub-optimal levels of zinc intake during gestation in the rat. J. Nutr., 107:1543-1550.

21. Halas, E.S., J.C. Wallwork, and H.H. Sandstead (1982) Mild zinc deficiency and undernutrition during the prenatal and postnatal periods in rats: Effects on weight, food consumption and brain catecholamine concentration. J. Nutr., 112:542-551.

22. Halsted, J.A., H.A. Ronaghy, P. Abadi, M. Haghshenass, G.H. Amirhakemi, R.M. Barakat, and J.G. Reinhold (1972) Zinc deficiency in man: The Shiraz experiment. Am. J. Med., 53:277-284.

23. Haumont, S. (1961) Distribution of zinc in bone tissue. J. Histochem. Cytochem., 9:141-145.

24. Haumont, S., and F.E. McLean (1966) Zinc and the physiology of bone. In: Zinc Metabolism. A.S. Prasad, ed. Charles C Thomas, Springfield, IL, pp. 169-186.

25. Haumont, S., and J. Vincent (1961) Zn et calcification du squelette. Experientia, 17:296-297.

26. Hickory, W., R. Nanda, and F.A. Catalanotto (1979) Fetal skeletal malformations associated with moderate zinc-deficiency during pregnancy. J. Nutr., 109: 883-891.

27. Huber, A.M., and S.N. Gershoff (1973) Effects of dietary zinc on zinc enzymes in the rat. J. Nutr., 103:1175-1181.

28. Hurley, L.S. (1981) Teratogenic aspects of manganese, zinc, and copper nutrition. Physiol. Rev., 61:249-295.

29. Hurley, L.S., and G. Cosens (1974) Reproduction and prenatal development in relation to dietary zinc level. In: Trace Element Metabolism in Animals-2. W.G. Hoekstra, J.W. Suttle, H.E. Ganther, and W. Mertz, eds. University Park Press, Baltimore, pp. 516-518.

30. Hurley, L.S., J. Gowan, and G. Milhaud (1969) Calcium metabolism in manganesedeficient and zinc-deficient rats. Proc. Soc. Exp. Biol. Med., 130:856-860.

31. Hurley, L.S., C.L. Keen, and B. Lönnerdal (1983) Aspects of trace element interactions during development. Fed. Proc. 42:1735-1739.

32. Hurley, L.S., and P.B. Mutch (1973) Prenatal and post-natal development after transitory gestational zinc deficiency in rats. J. Nutr., 103:649-656.

33. Hurley, L.S., and H. Swenerton (1966) Congenital mal-formations resulting from zinc deficiency in rats. Proc. Soc. Exp. Biol. Med., 123:692-696.

34. Hurley, L.S., and H. Swenerton (1971) Lack of mobilization of bone and liver zinc under teratogenic conditions of zinc deficiency in rats. J. Nutr., 101:597-603.

35. Hurley, L.S., and S.H. Tao (1972) Alleviation of teratogenic effects of zinc deficiency by simultaneous lack of calcium. Am. J. Physiol., 222:322-325.

36. Kimmel, C.A., and C. Trammell (1981) A rapid procedure for routine double staining of cartilage and bone in fetal and adult animals. Stain Technol., 56:271-273.

37. Kimmel, C.A., and J.G. Wilson (1973) Skeletal deviations in rats: Malformations or variations. Teratology, 8:309-316. 
38. Leek, J.C., C.L. Keen, J.B. Vogler, M.S. Golub, L.S. Hurley, A.G. Hendrickx, and M.E. Gershwin (1988) Long-term marginal zinc deprivation in rhesus monkeys. IV. Effects on skeletal growth and mineralization. Am. J. Clin. Nutr., 47:889-895.

39. Leek, J.C. J.B. Vogler, M.E. Gershwin, M.S. Golub, L.S. Hurley, and A.G. Hendrickx (1984) Studies of marginal zinc deprivation in rhesus monkeys. V. Fetal and infant skeletal defects. Am. J. Clin. Nutr., 40:1203-1212.

40. Lema, O., and H.H. Sandstead (1970) Zinc deficiency: Effect on epiphyseal growth. Clin. Res., 18:458.

41. Masters, D.G., C.L. Keen, B. Lönnerdal, and L.S. Hurley (1983) Zinc deficiency teratogenicity: The protective role of maternal tissue catabolism. J. Nutr., 113:905912.

42. Matsuzawa, T., and H.C. Anderson (1971) Phosphatases of epiphyseal cartilage studied by electron microscopic cytochemical methods. J. Histochem. Cytochem., 19: 801-808.

43. Murray, E.J., and H.H. Messner (1981) Turnover of bone zinc during normal and accelerated bone loss in rats. J. Nutr., 111:1941-1947.

44. Oner, G., B. Bhaumick, and R.M. Bala (1984) Effect of zinc deficiency on serum somatomedin levels and skeletal growth in young rats. Endocrinology, 114: 18601863.

45. Philip, B., and P.A. Kurup (1978) Dietary zinc and levels of collagen, elastin and carbohydrate components of glycoproteins of aorta, skin and cartilage in rats. Indian J. Exp. Biol., 16:370-372.

46. Prasad, A.S., and D. Oberleas (1971) Changes in activities of zinc-dependent enzymes in zinc-deficient tissues in rats. J. Appl. Physiol., 31:842-846.

47. Prasad, A.S., D. Oberleas, P. Wolf, J.P. Horwitz, R. Collins, and J.M. Vazquez (1967) Studies on zinc deficiency: Changes in trace elements and enzyme activities in tissues of zinc-deficient rats. J. Clin. Invest., 46:549-557.

48. Reinstein, N.H., B. Lönnerdal, C.L. Keen, and L.S. Hurley (1984) Zinc-copper interactions in rat: Fetal outcome and maternal and fetal zinc, copper, and iron. J. Nutr., 114:1266-1279.

49. Rest, J.R. (1976) The histological effects of copper and zinc on chick embryo skeletal tissues in organ culture. Br. J. Nutr., 36:243-254.

50. Rogers, J.M., C.L. Keen, and L.S. Hurley (1985) Zinc deficiency in pregnant LongEvans hooded rats: Teratogenicity and tissue trace elements. Teratology, 31: 89100.

51. Ronaghy, H.A., J.G. Reinhold, M. Mahloudji, P. Ghavami, M.R. Spivey Fox, and J.A. Halsted (1974) Zinc supplementation of malnourished school-boys in Iran: Increased growth and other effects. Am. J. Clin. Nutr., 27:112-121.

52. Roth, H.P., and M. Kirchgessner (1974) Zum Einfluss unterschiedlicher Diätzinkgehalte auf die Activität der alkalischen Phosphatase im Knochem. Z. Tierphysiol. Tierernähr. Futtermittelkunde, 33:57-61.

53. Salomon, C.D. (1974) A fine structural study on the extracellular activity of alkaline phosphatase and its role in calcification. Calcif. Tissue Res., 15:201-212.

54. Starcher, B.C., C.H. Hill, and J.C. Madaras (1980) Effect of zinc deficiency on bone collagenase and collagen turnover. J. Nutr., 110:2095-2102.

55. Suwarnasarn A., J.C. Wallwork, G.I. Lykken, F.N. Low, and H.H. Sandstead (1982) Epiphyseal plate development in the zinc-deficient rat. J. Nutr., 112: 1320-1328.

56. Vincent, J. (1963) Microscopic aspects of mineral metabolism in bone tissue with special reference to calcium, lead and zinc. Clin. Orthop., 26:161-175. 
57. Vojnik, C., and L.S. Hurley (1978) Abnormal prenatal lung development resulting from maternal zinc deficiency in rats. J. Nutr., 107:862-872.

58. Wallwork, J.C., C.J. Fosmire, and H.H. Sandstead (1981) Effect of zinc deficiency on appetite and plasma amino-acid concentrations in the rat. Br. J. Nutr., 45:127136.

59. Walker, B.E., and J. Kelleher (1978) Plasma, whole blood and urine zinc in the assessment of zinc deficiency in the rat. J. Nutr., 108:1702-1707.

60. Williams, R.B., N.T. Davis, and I. McDonald (1977) The effects of pregnancy and lactation on copper and zinc retention in the rat. Br. J. Nutr., 38:407-416.

61. Williams, R.B., and C.F. Mills (1970) The experimental production of zincdeficiency in the rat. Br. J. Nutr., 24:989:1003.

62. Wilson, J.G. (1965) Embriologic considerations in teratology. In: Teratology; Principles and Techniques. J.G. Wilson and J. Warkany, eds. University of Chicago Press, Chicago, pp. 251-277.

63. Yamaguchi, M., and T. Sakashita (1986) Enhancement of vitamin $\mathrm{D}_{3}$ effect on bone metabolism in weanling rats orally administered zinc sulphate. Acta Endocrinol., $111: 285-288$.

64. Yamaguchi, M., and R. Yamaguchi (1986) Action of zinc on bone metabolism in rats: Increases in alkaline phosphatase activity and DNA content. Biochem. Pharmacol., 35:773-777. 


\begin{tabular}{|c|c|}
\hline \multicolumn{2}{|c|}{ Table 1. Diet composition (\%) } \\
\hline Sprayed egg white $^{1}$ & 25.0 \\
\hline Vitamin $\operatorname{mix}^{2}$ & 1.5 \\
\hline Salt mix $^{3}$ & 6.0 \\
\hline Sucrose & 59.5 \\
\hline Corn oil & 8.0 \\
\hline \multicolumn{2}{|c|}{$\begin{array}{l}{ }^{2} \text { Composition of vitamin mix in grams per kilogram (prepared by } \\
\text { EDDA-Uniasa, Granada, Spain): inositol, } 25 \text {; ascorbic acid, } 5 \text {; Ca } \\
\text { pantothenate, } 2.5 \text {; thiamine HCI, } 1.5 \text {; pyridoxine, } 1.5 \text {; nicotinic acid, } \\
1.5 \text {; menadione (vitamin } \mathrm{K} \text { ), } 1.25 \text {; riboflavin, } 0.5 \text {; } \text {-aminobenzoic } \\
\text { acid, } 0.5 \text {; folic acid, } 0.03 \text {; biotin, } 0.2695 \text {; vitamin } \mathrm{E}, 11.9 \text {; vitamin } \mathrm{A} \text {, } \\
2.73 \text {; vitamin } \mathrm{D}, 0.23 \text {; vitamin } \mathrm{B}_{12}, 1.5 \text {; cerelose, } 895 \text {; choline } \mathrm{Cl} \\
\text { (70\% solution), } 71.5 \mathrm{ml} \text {. }\end{array}$} \\
\hline $\begin{array}{l}{ }^{3} \text { Composition of sal } \\
\text { Unisa, Granada, Spa } \\
\mathrm{K}_{2} \mathrm{HPO}_{4}, 321 ; \mathrm{FeSQ} \\
\mathrm{CrK}\left(\mathrm{SO}_{4}\right)_{2} \cdot 12 \mathrm{H}_{2} \mathrm{O} \\
\text { (only in control diet }\end{array}$ & $\begin{array}{l}\text { prepared by EDDA- } \\
\mathrm{CaHPO}_{4}, 60 \\
\mathrm{O}_{4} \cdot 5 \mathrm{H}_{2} \mathrm{O}, 0.66 \\
\mathrm{I}, 0.20 ; \mathrm{ZnCO}_{3}\end{array}$ \\
\hline
\end{tabular}

Table 2. Food intake and weight gain of dams submitted to different dietary regimens ${ }^{1,2,3}$

\begin{tabular}{|l|c|c|c|c|}
\hline & $\mathrm{ZD}(\mathrm{n}=8)$ & $\mathrm{PF}(\mathrm{n}=8)$ & $(\mathrm{n}=8)$ & $\mathrm{P}($ ANOVA $)$ \\
\hline Food intake $(\mathrm{g})$ & $237.5 \pm 16.5^{\mathrm{a}}$ & $236.7 \pm 15.5^{\mathrm{a}}$ & $380.0 \pm 32.1^{\mathrm{b}}$ & $<.001$ \\
\hline Total weight gain $(\mathrm{g})$ & $10 \pm 11^{\mathrm{a}}$ & $51 \pm 18^{\mathrm{b}}$ & $163 \pm 16^{\mathrm{c}}$ & $<.001$ \\
\hline Net weight gain $(\mathrm{g})^{4}$ & $-19 \pm 14^{\mathrm{a}}$ & $-5 \pm 13^{\mathrm{b}}$ & $88 \pm 11^{\mathrm{c}}$ & $<.001$ \\
\hline Food efficiency $^{5}$ & $0.0405 \pm 0.0452^{\mathrm{a}}$ & $0.2128 \pm 0.0705^{\mathrm{b}}$ & $0.4284 \pm 0.0317^{\mathrm{c}}$ & $<.001$ \\
\hline
\end{tabular}

${ }^{1} \mathrm{n}$, number of dams in each group.

${ }^{2}$ Values shown are means \pm SD.

${ }^{3}$ Values in the same row with different superscripts are significantly different by Duncan's multiple range test $(P<.05)$.

${ }^{4} \mathrm{Net}$ weight gain $=$ total weight gain - weight of fetuses, placentae, and membranes .

${ }^{5}$ Food efficiency $=$ total weight gain per food intake. 
Table 3. Weight of dams submitted to different dietary regimens on days 0,5 , 10,15 and 21 of gestation $1,2,3$

\begin{tabular}{|c|c|c|c|c|}
\hline Day & ZD & PF & $\mathbf{C}$ & P(ANOVA) \\
\hline 0 & $201 \pm 7$ & $204 \pm 10$ & $196 \pm 10$ & NS \\
\hline 5 & $-^{4}$ & $219 \pm 9$ & $222 \pm 8$ & NX \\
\hline 10 & $219 \pm 14^{\mathrm{a}}$ & $225 \pm 14^{\mathrm{a}}$ & $245 \pm 8^{\mathrm{b}}$ & $<.002$ \\
\hline 15 & $223 \pm 15^{\mathrm{a}}$ & $237 \pm 10^{b}$ & $276 \pm 8^{b}$ & $<.001$ \\
\hline 21 & $211 \pm 12^{\mathrm{a}}$ & $255 \pm 17^{b}$ & $358 \pm 16^{c}$ & $<.001$ \\
\hline \multicolumn{5}{|c|}{$\begin{array}{l}1 \mathrm{n}, \text { number of dams in each group. } \\
{ }^{2} \text { Values shown are means } \pm \text { SD. } \\
{ }^{3} \text { Values in the same row with different superscripts are significantly different by } \\
\text { Duncan's multiple range test }(P<.05) . \\
{ }^{4} \text { Not measured. }\end{array}$} \\
\hline
\end{tabular}

Table 4. Reproductive parameters in dams submitted to different dietary regimens ${ }^{1,2}$

\begin{tabular}{|c|c|c|c|c|}
\hline Reproductive parameters & $\mathrm{ZD}(\mathrm{n}=8)$ & PF $(n=8)$ & $C(n=8)$ & $\mathbf{P}^{3}$ \\
\hline Implantation sites per litter $^{4}$ & $12.9 \pm 1.8$ & $13.9 \pm 2.4$ & $12.6 \pm 2.2$ & $\mathrm{NS} \dagger$ \\
\hline Live fetuses per litter ${ }^{4}$ & $9.6 \pm 2.9^{\mathrm{a}}$ & $13.2 \pm 2.1^{b}$ & $11.9 \pm 2.0^{\mathrm{a}, \mathrm{b}}$ & $<.02 \dagger$ \\
\hline Fetal weight $^{5}$ & $2.43 \pm 0.50^{\mathrm{a}}$ & $3.54 \pm 0.61^{b}$ & $5.46 \pm 0.19^{c}$ & $<.001 \uparrow$ \\
\hline \multicolumn{5}{|l|}{ Resorptions } \\
\hline Percent of implantation sites & $25.2 *$ & $4.5^{* *}$ & $5.9 * *$ & $<.001 \ddagger$ \\
\hline Litters with resorptions & $6 / 8$ & $3 / 8$ & $6 / 8$ & \\
\hline \multicolumn{5}{|l|}{ Malformations $^{6}$} \\
\hline Percent of live fetuses & $98.7 *$ & $1.9 * *$ & $0 * *$ & $<.001 t$ \\
\hline Litters with malformations & $8 / 8$ & $1 / 8$ & 0 & \\
\hline \multicolumn{5}{|l|}{ Sites affected $^{7}$} \\
\hline Percent of implantation sites & $99.0 *$ & $5.4 * *$ & $5.9 * *$ & $<.001 t$ \\
\hline Litters affected & $8 / 8$ & $4 / 8$ & $6 / 8$ & \\
\hline \multicolumn{5}{|c|}{$\begin{array}{l}{ }^{1} \mathrm{n} \text {, number of dams in each group. } \\
{ }^{2} \text { Values in the same row with different superscripts are significantly different }(P<.05) \text { by Dunc } \\
\text { multiple range test (alphabetical superscripts) and chi-squared test (asterisks). } \\
{ }^{3} \text { ANOVA } P \text { value }(\dagger) \text { or chi-square } P \text { value }(\dagger) \\
{ }^{4} \text { Values shown are means } \pm \text { SD. } \\
{ }^{5} \text { Values shown are means of litter means SD. } \\
6 \text { Malformations detected by external observation or by examination of fetal skeleton in stained } \\
\text { specimens. } \\
{ }^{7} \text { Resorptions and malformations. }\end{array}$} \\
\hline
\end{tabular}




\begin{tabular}{|c|c|c|}
\hline Malformation & Affected fetuses $(\%)^{2}$ & Litters affected \\
\hline \multicolumn{3}{|l|}{ Head } \\
\hline Exencephaly & 1 & 1 \\
\hline Meningoencephalocele & 8 & 3 \\
\hline Meningocele & 19 & 4 \\
\hline Hydrocephaly & 4 & 1 \\
\hline Microphthalmia & 17 & 2 \\
\hline Micrognathia & 35 & 5 \\
\hline \multicolumn{3}{|l|}{ Trunk } \\
\hline Umbilical hernia & 12 & 4 \\
\hline Gastroschisis & 27 & 5 \\
\hline \multicolumn{3}{|l|}{ Forelimbs $^{2}$} \\
\hline Syndactyly & $44(65)$ & 7 \\
\hline Shortening & $21(100)$ & 3 \\
\hline Dysplasia $^{3}$ & $17(85)$ & 3 \\
\hline Oligodactyly & $40(84)$ & 7 \\
\hline \multicolumn{3}{|l|}{ Hindlimbs $^{2}$} \\
\hline Syndactyly & $12(33)$ & 5 \\
\hline Shortening & $17(100)$ & 3 \\
\hline Dysplasia & $53(80)$ & 6 \\
\hline Oligodactyly & $4(0)$ & 2 \\
\hline Extra elements & $3(100)$ & 1 \\
\hline \multicolumn{3}{|l|}{ Tail } \\
\hline Short $^{4}$ & 3 & 2 \\
\hline Angulated & 3 & 2 \\
\hline Wavy & 26 & 4 \\
\hline Curly & 57 & 6 \\
\hline \multicolumn{3}{|c|}{${ }^{1}$ All fetuses (77) from all litters (8) examined. } \\
\hline \multicolumn{3}{|c|}{${ }^{2}$ Percentage of bilateral defects in brackets. } \\
\hline \multicolumn{3}{|l|}{${ }^{3}$ Predominantly lateral. } \\
\hline \multicolumn{3}{|c|}{${ }^{4}$ Only fetuses that did not present any other defect of the tail. } \\
\hline
\end{tabular}




\begin{tabular}{|c|c|c|}
\hline Malformation $^{2}$ & $\begin{array}{l}\text { Fetuses } \\
\text { affected }\end{array}$ & $\begin{array}{c}\text { Litters } \\
\text { affected }^{3}\end{array}$ \\
\hline \multicolumn{3}{|l|}{ Head (44) } \\
\hline Micrognathia & 25.0 & 3 \\
\hline \multicolumn{3}{|l|}{ Spine (43) } \\
\hline Fused vertebrae & 41.9 & 6 \\
\hline Hemivertebrae & 74.4 & 7 \\
\hline \multicolumn{3}{|l|}{ Tail (35) } \\
\hline Short & 71.4 & 6 \\
\hline Fused vertebrae & 95.2 & 8 \\
\hline Malformed & 97.1 & 8 \\
\hline \multicolumn{3}{|l|}{ Ribs (43) } \\
\hline Absent & $69.8^{4}$ & 7 \\
\hline Short & 30.2 & 5 \\
\hline Fused & 7.0 & 2 \\
\hline Dysplastic & 25.6 & 5 \\
\hline \multicolumn{3}{|l|}{ Sternum (30) } \\
\hline Absent & 46.7 & 5 \\
\hline Fused ossification nuclei & 3.3 & 1 \\
\hline \multicolumn{3}{|l|}{ Forelimbs: arm and forearm (44) } \\
\hline Curved humerus & 2.3 & 1 \\
\hline Synarthrosis (elbow) ${ }^{5}$ & 18.2 & 1 \\
\hline Dysplasia and/or hypoplasia of ulna and radius & 25.0 & 4 \\
\hline \multicolumn{3}{|l|}{ Forelimbs: hands (42) } \\
\hline Fused metacarpals & 11.9 & 4 \\
\hline Transversally fused phalanges $^{6}$ & 11.9 & 5 \\
\hline Longitudinal synchondrosis (carpus and phalanges) & 2.4 & 1 \\
\hline Clinodactyly & 19.0 & 3 \\
\hline Digital hypoplasia & 4.8 & 2 \\
\hline Oligodactyly ${ }^{7}$ & 57.1 & 7 \\
\hline Duplication & 2.4 & 1 \\
\hline \multicolumn{3}{|l|}{ Hindlimbs: Thigh and leg (41) } \\
\hline Hypoplastic femur & 19.5 & 3 \\
\hline Hypoplastic tibia & 14.6 & 2 \\
\hline Dysplastic tibia & 24.4 & 5 \\
\hline Absent fibula & 4.9 & 1 \\
\hline Hypoplastic fibula & 24.4 & 5 \\
\hline \multicolumn{3}{|l|}{ Hindlimbs: feet (38) } \\
\hline Fused metatarsals & 15.8 & 2 \\
\hline Transversally fused phalanges ${ }^{6}$ & 2.6 & 1 \\
\hline Clinodactyly & 2.6 & 1 \\
\hline Digital hypoplasia & 5.3 & 1 \\
\hline Oligodactyly $^{7}$ & 23.7 & 4 \\
\hline Duplication & 2.6 & 1 \\
\hline \multicolumn{3}{|c|}{$\begin{array}{l}{ }^{1} \text { Does not include calcification defects. }{ }^{2} \text { Number of specimens examined in bracket } \\
{ }^{3} \text { Eight litters examined. }{ }^{4} \text { Total absence in } 25.6 \% \text { and partial absence in } 44.2 \% \text {. } \\
{ }^{5} \text { Synchondrosis, except for one fetus that presented unilateral synostosis. } \\
{ }^{6} \text { Whether or not accompanied by fusion of metacarpals or metatarsals. } \\
{ }^{7} \text { Includes total and partial ectrodactylies. }\end{array}$} \\
\hline
\end{tabular}


Table 7. Ossification nuclei of fetuses from dams submitted to different dietary regimens ${ }^{1,2,3}$

\begin{tabular}{|l|c|c|c|c|}
\hline Location & ZD & PF & C & P (ANOVA) \\
\hline Sternum & $(16) 1.95 \pm 1.42^{\mathrm{a}}$ & $(74) 4.56 \pm 0.88^{\mathrm{b}}$ & (57) $5.45 \pm 0.69^{\mathrm{b}}$ & $<.001$ \\
\hline Hands $^{4}$ & $(80) 1.96 \pm 0.95^{\mathrm{a}}$ & $(146) 5.50 \pm 1.60^{\mathrm{b}}$ & $(116) 6.61 \pm 0.59^{\mathrm{b}}$ & $<.001$ \\
\hline Feet $^{5}$ & $(69) 2.57 \pm 1.20^{\mathrm{a}}$ & $(147) 3.96 \pm 0.07^{\mathrm{b}}$ & (124) $4.22 \pm 0.22^{\mathrm{b}}$ & $<.001$ \\
\hline
\end{tabular}

${ }^{1}$ Number of specimens examined in brackets.

${ }^{2}$ Values shown are means of litter means \pm SD

${ }^{3}$ Values in the same row with different superscripts are significantly different by Duncan's multiple range test $(P<.05)$.

${ }^{4}$ Metacarpals and anterior proximal phalanges.

${ }^{5}$ Metatarsals.

Table 8. Effect of gestational zinc deficiency on concentrations of zinc, calcium, and phosphorus in maternal and fetal tissues ${ }^{1,2,3}$

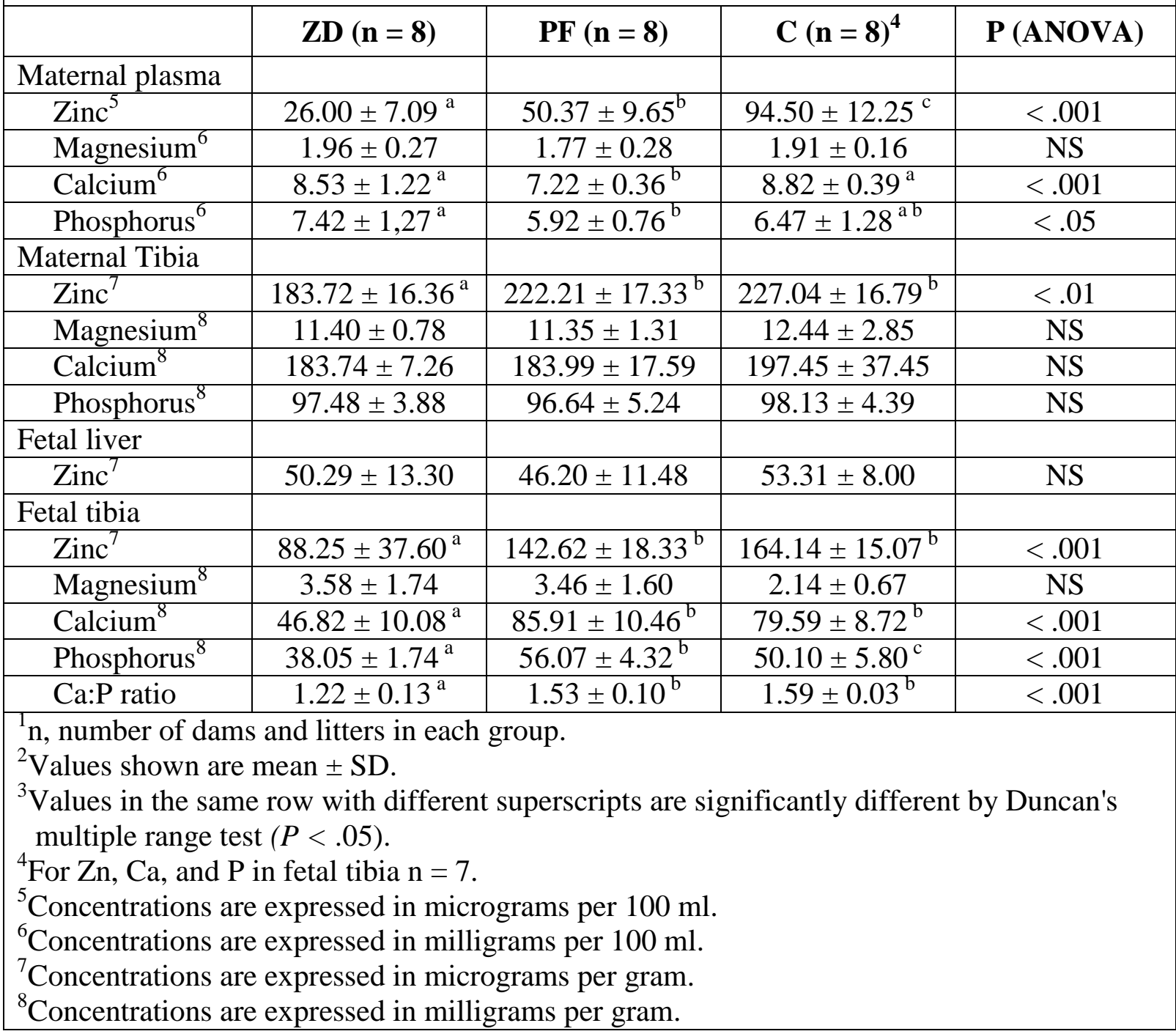




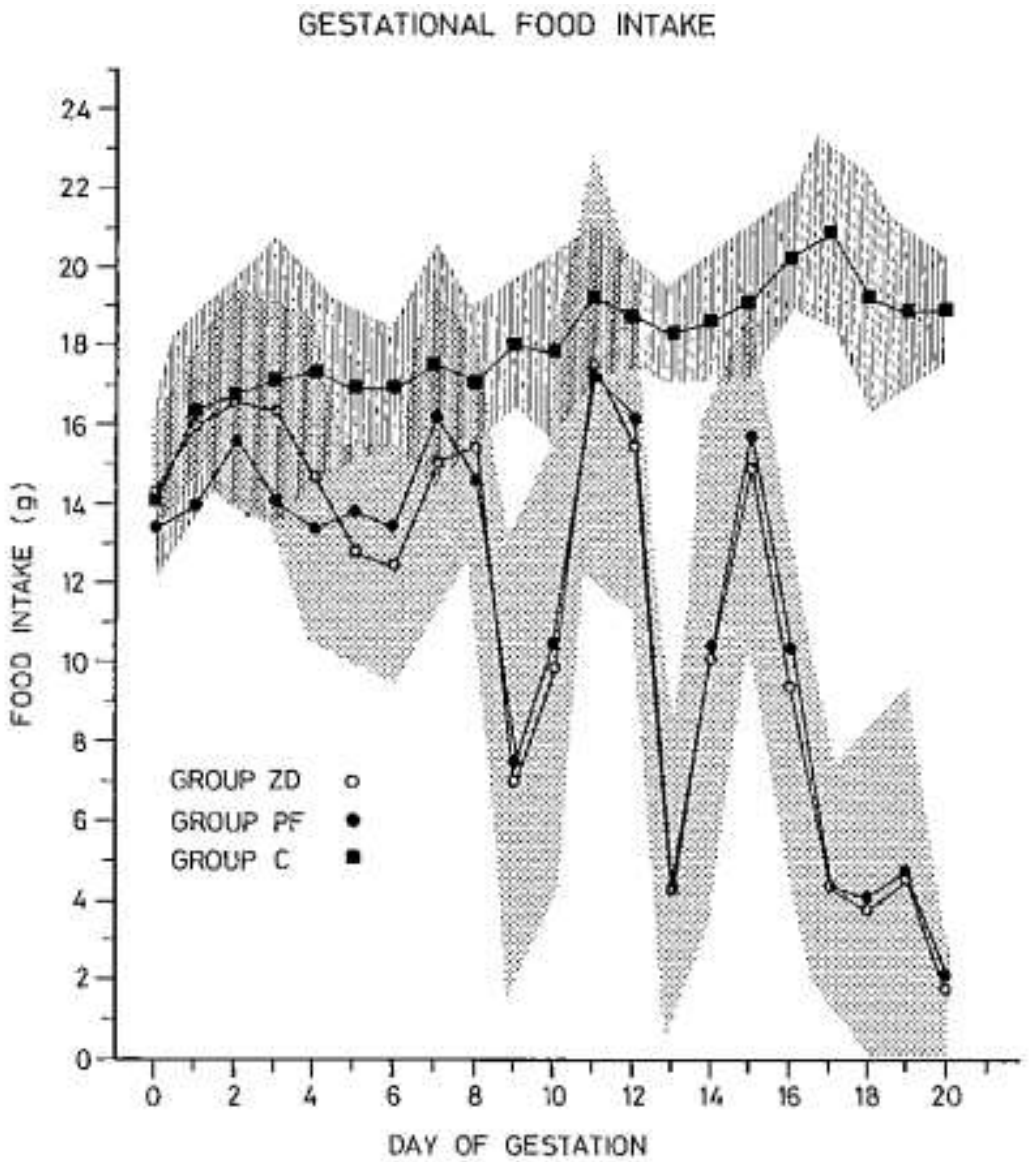

Figure 1. Food intake during pregnancy of dams submitted to different dietary regimens.
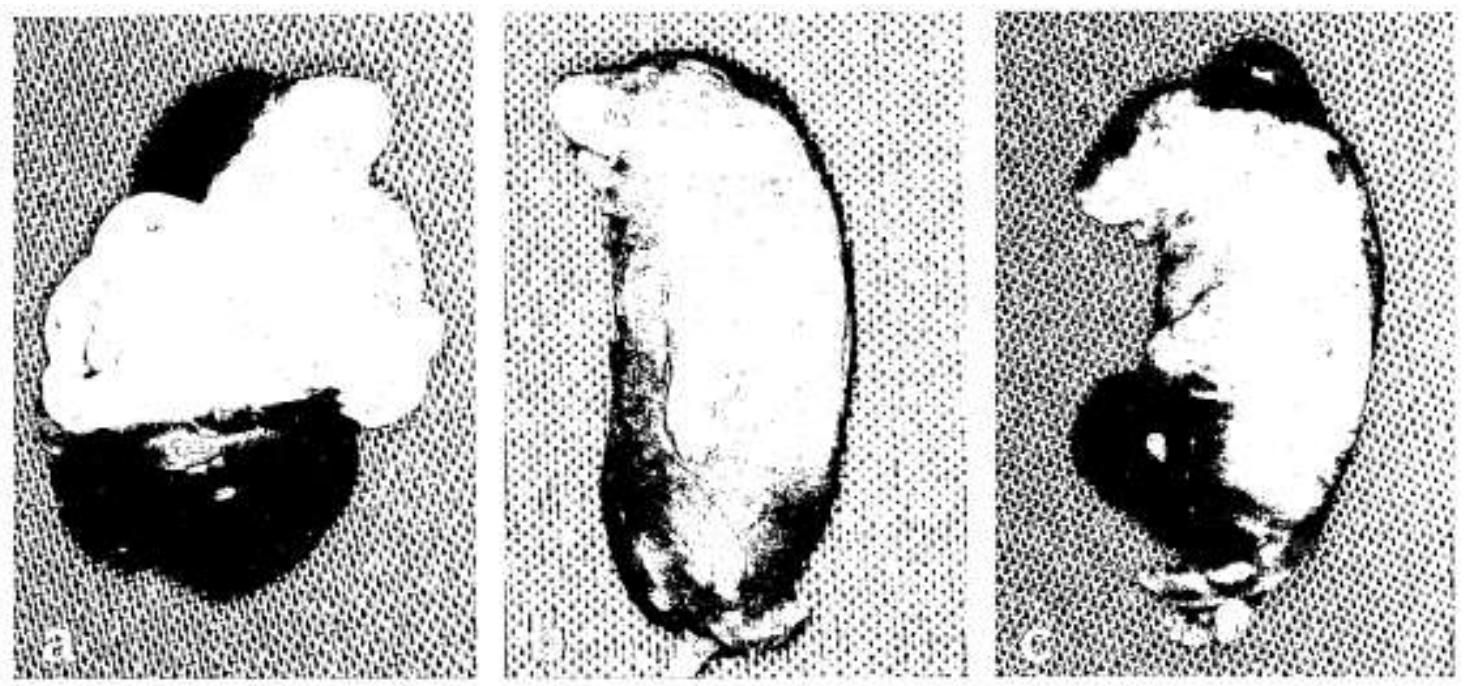

Figure 2. Fetuses from ZD dams at day 21 of gestation. Note a: exencephaly; c: meningoencephalocele; b,c: microphthalmia; b,c: micrognathia; a,c: gastroschisis; a-c: shortened and dysplastic extremities; b: lateral deviation of the hand; b: oligodactyly, and a: shortened angulated and b,c: curly tail. 


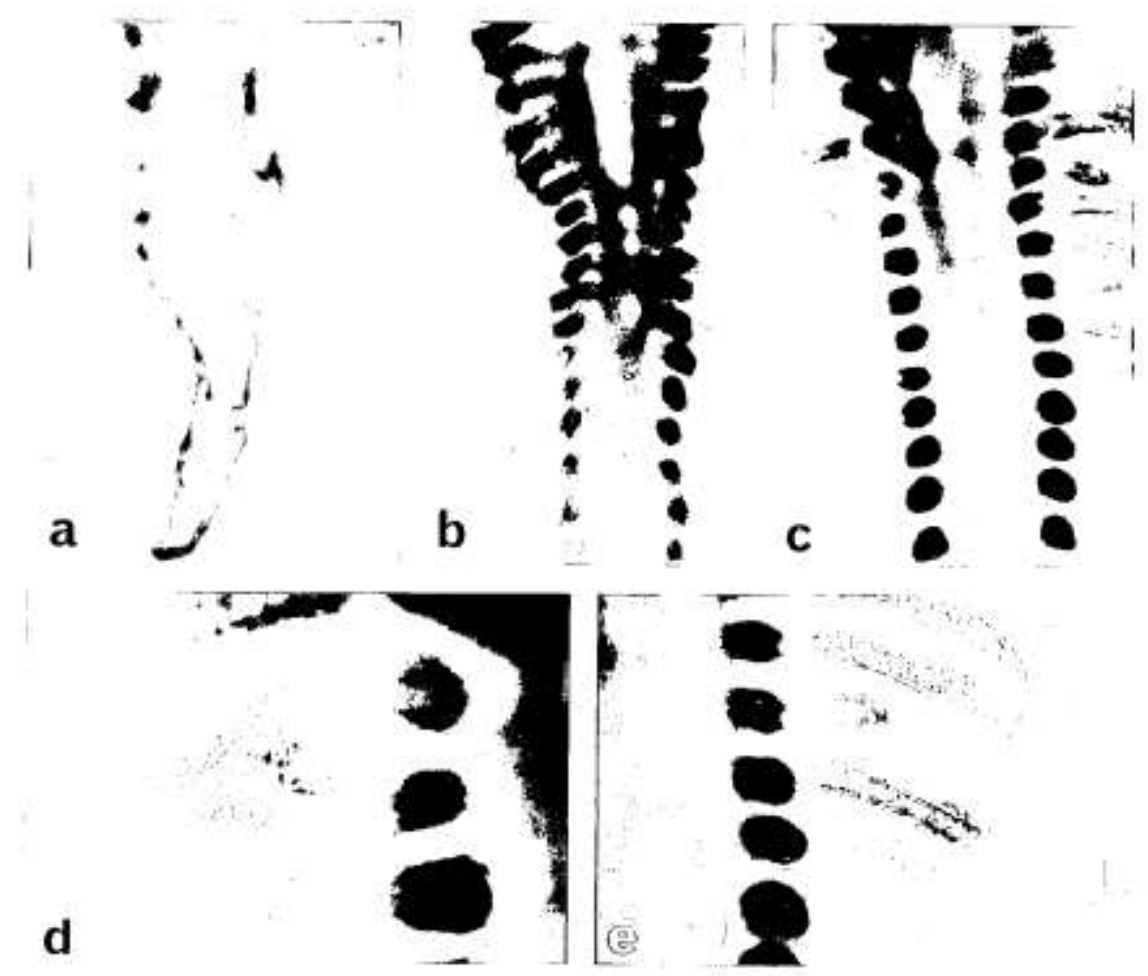

Figure 3. Skeletal defects in stained and cleared fetuses from ZD dams at day 21 of gestation. a: Short tail with fused vertebrae and spina bifida. b,c: Spine with fused vertebrae and hemivertebrae. b: Total and c: partial absence of ribs, and c-e: short, fused, and malformed ribs.

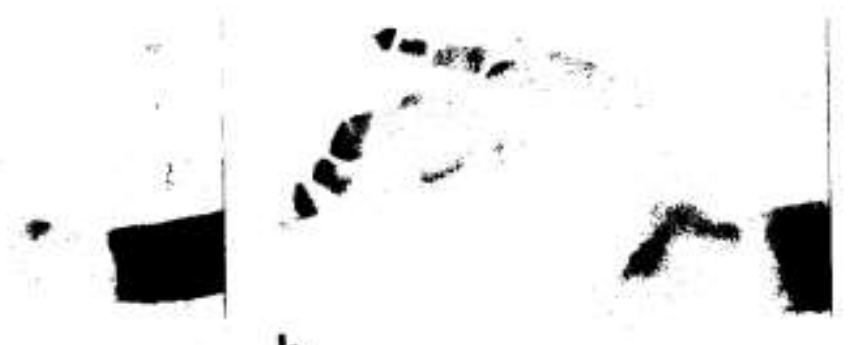

a

b

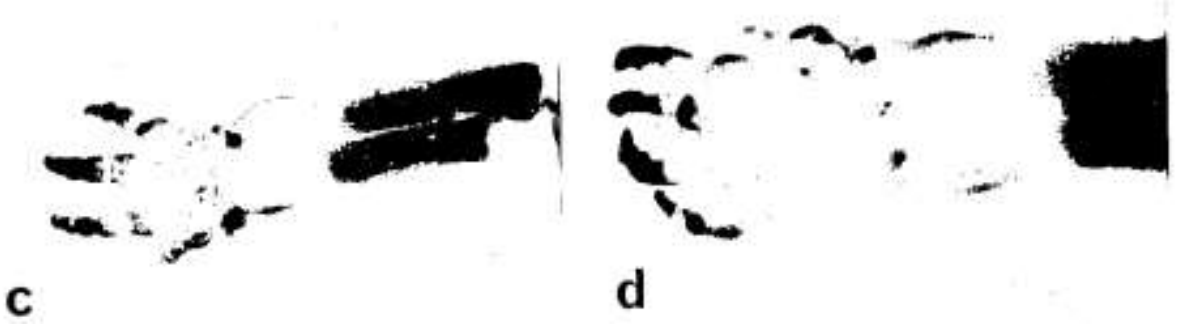

Figure 4. Skeletal malformations of forelimbs in stained fetuses from ZD dams at day 21 of gestation. a,b: Synarthrosis of the elbow and dysplastic bones of the forearm; a,b,d: fused carpal bones; b,d: fused metacarpals; b,d: transversally fused phalanges, and a-c: oligodactyly. 

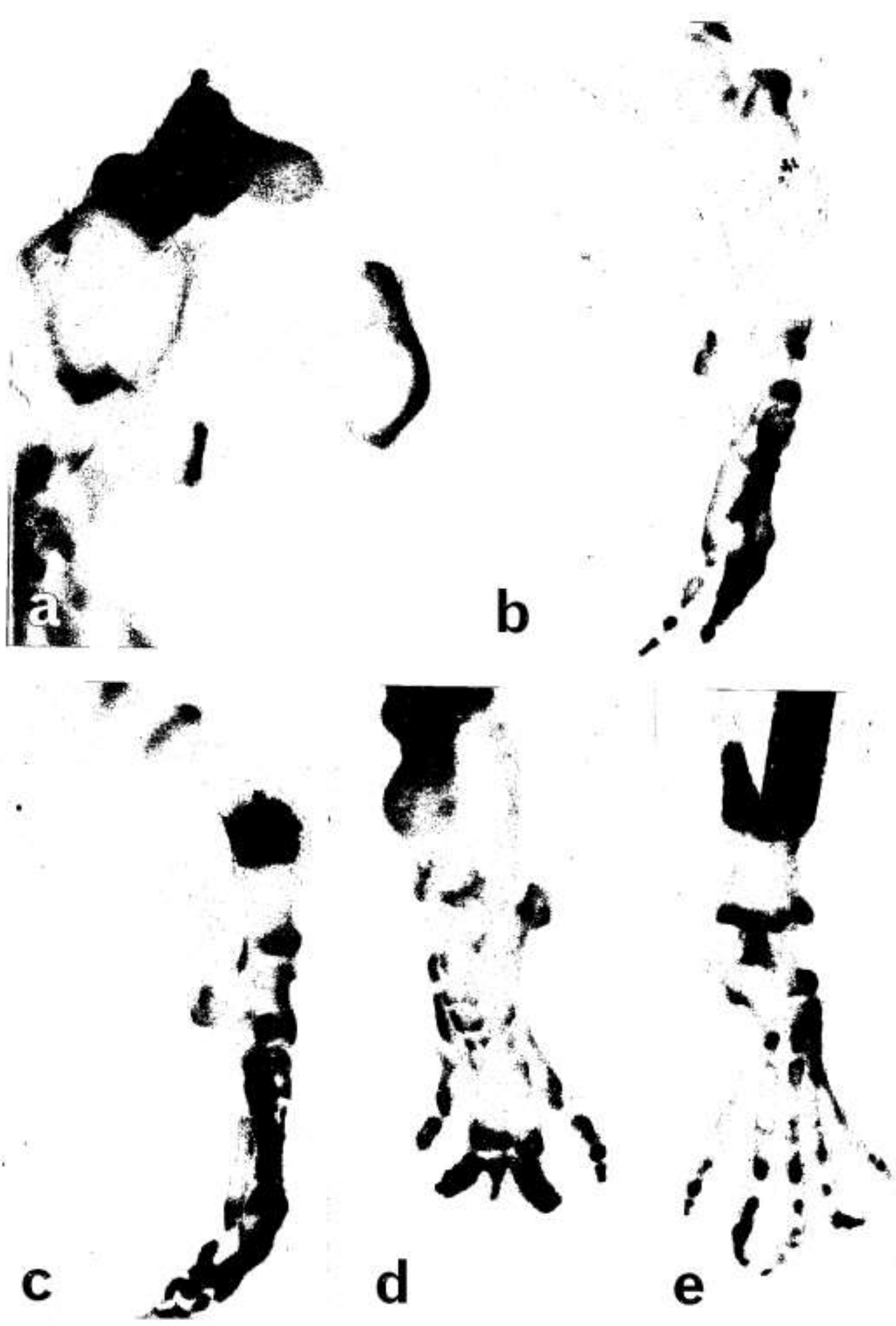

Figure 5. Skeletal malformations of hind limbs in stained fetuses from ZD dams at day 21 of gestation. a-c: Hypoplastic femur; a-d: hypoplastic and dysplastic tibia and fibula; d: fused metatarsals and transverselly fused phalanges; e: clinodactyly; and d: digital hypoplasia. 